\title{
Mercedes Cunha Chaves de Carvalho: pioneira na Psicologia do Brasil
}

Não há como separar a história profissional de Mercedes Cunha Chaves de Carvalho da história da Psicologia no Brasil. Mercedes, nascida em 29 de julho de 1936, foi casada e mãe de quatro filhos, e um grande expoente na luta pelo reconhecimento da Psicologia como um curso de graduação legítimo no País. Mercedes Carvalho esteve por vários anos em sala de aula, contribuindo para a formação de diversos profissionais que puderam sentir de perto sua paixão pela Psicologia e pela Educação.

Na época em que cursava o ensino médio, a Filosofia fazia parte da grade curricular do seu colégio, e a Psicologia era considerada uma subdivisão da disciplina. Seu professor era Caio Faminio Silva de Carvalho, um aluno de Filosofia da Universidade Federal da Bahia (UFBA). Desde cedo, Mercedes encantou-se com a Psicologia, mas encontrou um grande obstáculo a sua frente: no Brasil não existia nenhum curso em nível superior na área.

Por isso, assim que terminou o ensino médio, Mercedes Carvalho decidiu ingressar no curso de Filosofia da UFBA, já por seu interesse por essa área e pelo fato de a graduação oferecer matérias relacionadas à Psicologia. Na época, além dessa opção, só a escola normal e algumas pós-graduações na Universidade de São Paulo (USP) ofereciam a formação mais aprofundada em Psicologia.

Na faculdade, teve aulas com o professor João Inácio de Mendonça, um grande defensor da criação do curso de Psicologia. Havia o temor de que a falta de formalidade da área pudesse permitir que pessoas pouco credenciadas ou qualificadas atuassem na prática profissional. Tendo em vista tal cenário, o professor João Inácio e outros professores, como Lourenço Filho e Enzo Azzi, além de alguns psiquiatras, reuniram-se em uma comissão com o objetivo de criar e regulamentar o curso de Psicologia. Nesse momento, o curso de Filosofia passou a ter cada vez mais disciplinas dessa área, com o objetivo de formar quadros para a futura graduação.

Por causa dessa mudança, Mercedes Carvalho se aprofundou nos estudos da Psicologia e passou a defender, com o professor João Mendonça, a criação do curso, objetivo que só foi alcançado após dez anos de luta, em 1968, quando a Universidade Federal da Bahia passou a oferecer a graduação em Psicologia. Nesse momento, Mercedes teve papel fundamental na formação do novo curso, uma vez que participou da equipe que elaborou o currículo da graduação e convidou os professores para darem as aulas do curso. Ela mesma começou lecionando duas disciplinas, uma delas intitulada Psicologia Geral.

Em 1976, iniciou sua pós-graduação na Universidade de São Paulo (USP), porém não concluiu o curso, e, de volta à Bahia, escreveu sua dissertação de mestrado em Educação pela UFBA, que foi defendida em 1979. Foi uma das autoras do projeto Auto das Pombas, no qual pôde experimentar os princípios da aprendizagem nas comunidades populares. Tal projeto foi tema da sua tese de doutorado, produzida entre 1979 e 1983, na USP.

Mercedes Carvalho se aposentou em 1990, o que não significou o encerramento de suas contribuições para a Psicologia e para a educação. Ministrou aulas na rede pública de ensino entre 1991 e 1995, e esteve em Sergipe contribuindo com a luta pelo reconhecimento do curso de Psicologia no Estado, que, apesar de já existir há sete anos, não havia sido reconhecido oficialmente como curso de graduação. Também em Sergipe, lecionou disciplinas como Observação do Comportamento, Teorias e Técnicas Psicoterápicas na base comportamental. Após dois anos nesse Estado, foi convidada a voltar para a Bahia a fim de criar o curso de Psicologia na Faculdade Ruy Barbosa, primeira instituição privada do Estado a oferecer a graduação na área.

O trabalho de Mercedes Carvalho obteve destaque em diversas áreas, principalmente em relação à análise de comportamento e à educação, para as quais se inspirou fortemente nos estudos de Paulo Freire. Além disso, autores como Bertrand Russel e Skinner influenciaram enormemente suas produções; foi cofundadora do Conselho Regional de Psicologia da Bahia e, em 1997, foi homenageada pelo Conselho Federal de Psicologia com o prêmio Contribuição no Desenvolvimento da Psicologia como Ciência e Profissão. Mercedes Carvalho faleceu em 24 de dezembro de 2010. 